\title{
Lettres d'un Lion. Correspondance inédite du général Mouton, comte de Lobau (1812-1815)
}

Jacques Logie

\section{(2) OpenEdition}

Édition électronique

URL : https://journals.openedition.org/ahrf/9593

DOI : 10.4000/ahrf.9593

ISSN : 1952-403X

Éditeur :

Armand Colin, Société des études robespierristes

Édition imprimée

Date de publication : 1 juin 2007

Pagination : 220-221

ISSN : 0003-4436

Référence électronique

Jacques Logie, « Lettres d'un Lion. Correspondance inédite du général Mouton, comte de Lobau

(1812-1815) », Annales historiques de la Révolution française [En ligne], 348 | Avril-Juin 2007, mis en

ligne le 23 juillet 2008, consulté le 27 avril 2022. URL : http://journals.openedition.org/ahrf/9593 ; DOI : https://doi.org/10.4000/ahrf.9593

Ce document a été généré automatiquement le 27 avril 2022.

Tous droits réservés 


\title{
Lettres d'un Lion. Correspondance inédite du général Mouton, comte de Lobau (1812-1815)
}

\author{
Jacques Logie
}

\section{RÉFÉRENCE}

Emmanuel de Waresquiel, Lettres d'un Lion. Correspondance inédite du général Mouton, comte de Lobau (1812-1815), Paris, Nouveau monde éditions, 2005, 207 p., ISBN

2-84736-088-3, $25 €$.

1 L'édition par E. de Waresquiel de la correspondance adressée par le général Mouton à sa femme pendant les campagnes de Russie (1812), d'Allemagne (1813) et de Belgique (1815), est d'un faible intérêt, notamment sur le plan de l'histoire militaire. Ces lettres permettent, tout au plus, de saisir une partie de la personnalité du comte de Lobau : un bourgeois aux armées, préoccupé de ses affaires domestiques, de l'état de sa très confortable et récente fortune, hostile à la noblesse dont Napoléon aimait s'entourer pendant les dernières années de son règne et méfiant à l'égard du monde paysan. Elles confirment que même les hommes proches de l'empereur étaient tenus à l'écart des prises de décisions, tant sur le plan militaire que diplomatique.

Ce fils d'un boulanger bourgeois de Phalsbourg, volontaire de 1792, longtemps républicain, était devenu aide-de-camp de l'empereur en 1805. Il avait épousé en 1809, par la volonté de Napoléon, une jeune-fille de dix-neuf ans, issue de l'aristocratie européenne, Félicité d'Arberg de Valengin. Manifestement, il fut très amoureux de cette femme de vingt ans sa cadette. La différence d'éducation entre les conjoints apparaît fugitivement dans le courrier. Ainsi, le général n'apprécie guère que son épouse sorte de sa sphère ménagère « pour philosopher à toute outrance ", ce qui selon lui, « ne sert presque jamais à rien ». 
3 Comme chez la plupart des militaires en campagne, le général demande obsessionnellement des nouvelles du pays et de la famille. Le ton de sa correspondance est très conventionnel: il informe de sa santé, donne des recommandations domestiques et témoigne d'une admiration sans borne pour l'empereur. S'agit-il d'un sentiment de façade formulé à l'intention du cabinet noir ou d'une réelle fascination pour les qualités militaires de Napoléon? L'état de santé de celui-ci est d'ailleurs au centre des préoccupations de son entourage, comme si le destin de la France en dépendait à chaque instant.

4 L'édition de cette correspondance est très soignée. L'introduction d'Emmanuel de Waresquiel cerne bien la personnalité de Lobau et replace le général dans son milieu. Il en est de même de la présentation des campagnes de 1812, 1813 et 1815. À propos de cette dernière, on peut regretter que de Waresquiel n'ait pas publié le récit de la bataille de Waterloo retrouvé dans les archives familiales (p. 175) et accorde du crédit au témoignage du chef d'état major de Lobau, Combes Brassart, totalement fantaisiste. Les lettres datées de 1815 ne concernent d'ailleurs que la captivité du général Mouton après Waterloo. Elles ne manquent pas d'intérêt, car elles mettent en évidence la condition des prisonniers de marque et le réseau de relations qu'ils peuvent mettre en œuvre. 